\title{
6.2. ЛИБЕРАЛИЗАЦИЯ РЫНКА КАПИТАЛА МАТЕРИКОВОГО КИТАЯ
}

Шуплецов А.Л., исполнительный директор Корпоративно-инвестиционного блока ПАО «Совкомбанк», г. Москва

На протяжении последних двух десятилетий Китай постепенно, но планомерно открывает свой национальный рынок капитала для иностранных инвесторов. К текущему моменту через так называемые мосты между биржами Шанхая, Шэньчжэня и Гонконга иностранным и китайским инвесторам доступно свыше 2000 акций для взаимной торговли.

Китайский фондовый рынок сегодня является одним из самых молодых (Шанхайской бирже, например, в этом году исполняется 29 лет), и в то же время самых привлекательных с точки зрения соотношения доходности и риска - развитые страны не демонстрируют ни ощутимой динамики экономического роста, ни доходности своих ценных бумаг, а сопоставимые по темпам экономического роста с китайскими Индия и Вьетнам не имеют таких объемов рынка. Например, США давно добивались открытия китайского рынка капитала, особенно после вступления Китая во Всемирную торговую организацию. Российские инвесторы также давно интересуются ценными бумагами китайских компаний, однако вплоть до 2014 г. они не имели простого механизма для их покупки. Начало работы на огромном рынке капитала Китая расширяет возможности российских инвесторов по диверсификации инвестиционных портфелей, что особенно актуально в условиях риска реализации различных санкционных запретов со стороны Великобритании, Европейского союза и США. С точки зрения двусторонних экономических отношений доступ российских инвесторов на китайский фондовый и долговой рынок может способствовать увеличению объема рынка валютных деривативов и, впоследствии, расширению и укреплению использования национальных валют в торговле между РФ и Китаем. В статье рассматриваются основные причины и этапы либерализации китайского рынка капитала, условия торговли через мосты Шанхай - Гонконг (Shanghai-Hong Kong Stock Connect) и Шэньчжэнь - Гонконг (Shenzhen-Hong Kong Stock Connect), перспективы дальнейшего начала работы на рынках капитала Китая.

\section{Литература}

1. Войны, госконтроль и азиатский NASDAQ: как возник фондовый рынок в Китае [Электронный ресурс]. - URL : https://quote.rbc.ru/news/training/5dad67d69a794725be7d7e5e.

2. Макарова А.Д. Фондовый рынок КНР, его биржи и индексы [Электронный ресурс] / А.Д. Макарова // Молодой ученый. - 2016. - №28. - C. 484-486. - URL : https://moluch.ru/archive/132/37016/.

3. Руденко П. Восточная доля: зачем российским инвесторам квота на китайском рынке [Электронный ресурс] / П. Руденко. URL : https://www.forbes.ru/finansy/rynki/ 271607-vostochnaya-dolya-zachem-rossiiskim-investoram-kvota-na-kitaiskom-rynke.

4. Теряева А.С. Межбанковский рынок облигаций Китая: особенности, направления либерализации [Электронный ресурс] / А.С. Теряева, Т.А. Журавлева // Фундаментальные исследования. - 2016. - №2 ; ч. 3. - С. 632-636. - URL : https://fundamental-research.ru/ru/article/ view?id=39988

5. Юсыпчук О.И. Фондовый рынок Китая (проблема взаимодействия иностранных эмитентов и инвесторов с фондовыми рынками) [Электронный ресурс] / О.И. Юсыпчук // Научное сообщество студентов XXI столетия. Экономические науки: сб. ст. по мат-лам XVIII междунар. студ. науч.-практ. конф. - 2014. - №3. - URL : http://sibac.info/archive/economy/3(18).pdf.

6. ETF [Electronic resource] : official website of the Foundation. - URL : https://www.etf.com/CN\#overview.

7. Hong Kong securities and investment institute [Electronic resource]. - URL : https://www.hksi.org/en/qualification/practisingqualifications/licensing-examination-for-securities-and-futures-intermediaries/overview/.

\section{Ключевые слова}

Рынок капитала Китая; либерализация китайского рынка капитала; торговля через мосты; Шанхайская, Шэньчжэньская и Гонконгская фондовые биржи; межбанковский рынок облигаций.

\section{Шуплецов Александр Леонидович}

\section{РЕЦЕНЗИЯ}

Статья исполнительного директора корпоративно-инвестиционного блока Публичного акционерного общества «Совкомбанк» А.Л. Шуплецова актуальна в качестве экспертного обзора этапов либерализации рынка инвестиций Китайской Народной Республики. Китайский фондовый рынок привлекателен для иностранных инвесторов с точки зрения динамики экономического роста, доходности ценных бумаг, соотношения доходности и риска. В настоящее время действуют механизмы взаимодействия с иностранными инвесторами QFII (Qualified Institutional Investor) или RQFII (Renminbi Qualified Institutional Investor). При этом государственное управление валютного контроля Китая отменило механизм QFII в части квотирования на покупку внутренних деривативов.

Автором интересно рассмотрена либерализация фондового рынка в КНР, начавшаяся с допуска к покупкам определенных видов ценных бумаг крупным и надежным институциональным инвесторам, благодаря чему были созданы предпосылки для обращения национальных ценных бумаг среди розничных иностранных инвесторов и инвесторов из Гонконга на втором этапе либерализации. Справедливо обращено внимание на использование механизмов регулирования экономических и финансовых взаимоотношений свободной экономической зоны в Гонконге.

Вызывает интерес мнение автора в отношении механизмов взаимодействия фондовых бирж Шанхая и Шэньчженя с фондовыми биржами Гонконга. Следует отметить, что взаимодействие с тихоокеанскими свободными экономическими зонами (СЭ3) создало для КНР беспрецедентные условия для развития технологичных и инновационных отраслей и привлечения иностранных инвесторов.

В обращении на Шанхайской фондовой бирже находятся акции типа А (торгуются за юани) и акции типа Б (для нерезидентов и номинированы в долларах США). Через брокеров Гонконгской фондовой биржи торгуются акции более чем 500 крупнейших компаний Шанхайской биржи.

Иностранные инвесторы могут приобретать акции более чем 880 компаний, котирующихся в Шэньчжэне через Гонконгскую фондовую биржу в рамках установленных квот (до 13 млрд. юаней), а брокеры Шэньчжэньской биржи могут подавать заявки на приобретение ценных бумаг с установленной квотой - 10,5 млрд. юаней).

Гонконгским законодательством регулируются все виды деятельности фондовой торговли: привлечение инвестиций на рынке ценных бумаг в Гонконге, размещение ценных бумаг, выкуп акций, сделки с крупными пакетами акций, конвертация облигаций. 
Автор считает, что допуск в 2017 г. иностранных инвесторов к покупкам облигаций на межбанковском рынке облигаций через мост Сһina Bond Connect следующим этапом либерализации фондового рынка Китая.

На сегодня акции практически всех классов обращаются через фонд ETF, все крупные и мелкие инвесторы могут приобретать акции и создавать портфели институционального уровня.

Автор обращает внимание на улучшение условий диверсификации инвестиций и расширение возможностей расчетов в национальных валютах.

Можно сделать вывод, что статья А.Л. Шуплецова удовлетворяет требованиям, предъявляемым к научным публикациям, и может быть рекомендована для публикации.

Барыкин С.Е., д.э.н., доцент, профессор, кафедра международных экономических отношений, Санкт-Петербургский государственный морской технический университет (ФГБОУ ВО «СПбГМТУ»), г. Санкт-Петербуре.

DOI 10.38097/AFA.2020.87.54.019 